\section{Commentary: The role of valve-sparing aortic root surgery in congenital heart disease}

\author{
Arshid Mir, MD, ${ }^{a}$ and Harold M. Burkhart, MD ${ }^{\mathrm{b}}$
}

Valve-sparing aortic root replacement (VSRR), when compared with prosthetic aortic valve and root replacement, has the advantages of native aortic valve hemodynamics, avoiding the complications associated with anticoagulation therapy, as well as longer durability versus a bioprosthetic valve. While the majority of data regarding this operation are derived from adult patients ${ }^{1,2}$ more recent data are emerging in the congenital world. ${ }^{3,4}$ As more information becomes available, it is clear that many questions are yet to be answered regarding the role of valve-sparing aortic root surgery in congenital heart disease.

In this issue of the Journal, Buratto and Konstantinov ${ }^{5}$ present a comprehensive, up-to-date expert technical review of VSRR with specific attention given to the congenital cardiac population. First, they review the indications, pointing out that there are still many unanswered questions in the congenital group. Next, they point out that although the majority of the pediatric VSRRs are performed in patients with connective tissue disorders, more literature involving patients with congenital cardiac disease is becoming available. ${ }^{3} \mathrm{~A}$ review of the most common techniques, the reimplantation (David) and remodeling (Yacoub), as well as other external supporting procedures (Robicsek, Florida sleeve and personalized external aortic root support) is then presented with appropriate illustrations. The last portion of the review highlights several key congenital studies accompanied by

\footnotetext{
From the ${ }^{\text {a Section }}$ of Pediatric Cardiology, and ${ }^{\mathrm{b}}$ Division of Cardiovascular and Thoracic Surgery, University of Oklahoma Health Sciences Center, Oklahoma City, Okla.

Disclosures: The authors reported no conflicts of interest.

The Journal policy requires editors and reviewers to disclose conflicts of interest and to decline handling or reviewing manuscripts for which they may have a conflict of interest. The editors and reviewers of this article have no conflicts of interest.

Received for publication Sept 15, 2020; revisions received Sept 15, 2020; accepted for publication Sept 16, 2020; available ahead of print Sept 19, 2020.

Address for reprints: Harold M. Burkhart, MD, Division of Cardiovascular and Thoracic Surgery, University of Oklahoma Health Sciences Center, P.O. Box 26901, WP-2230, Oklahoma City, OK 73105 (E-mail: Harold-burkhart@ouhsc. edu).

J Thorac Cardiovasc Surg 2021;162:965-6

0022-5223/\$36.00

Copyright (C) 2020 by The American Association for Thoracic Surgery

https://doi.org/10.1016/j.jtcvs.2020.09.063
}

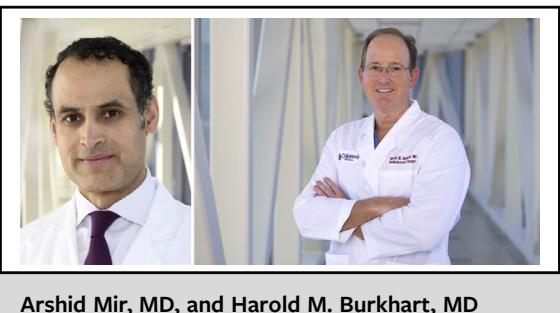

Arshid Mir, MD, and Harold M. Burkhart, MD

CENTRAL MESSAGE

The surgical management of

aortic root aneurysms in

congenital cardiac patients has

evolved, taking cues from the

adult acquired cardiac literature.

However, much remains to be

learned.

an extensive reference list, most of which are associated with the American Association for Thoracic Surgery and this Journal.

After reading this current expert review of what is published on VSRR in the congenital population, one can see that many uncertainties remain. When considering indications for surgical intervention for prophylactic aortic root surgery in pediatric patients with connective tissue disorders, one should note that most of the recommendations are currently based on adult guidelines. The use of an absolute threshold size in making treatment decisions in children is difficult, since it has not been shown to correlate with aortic complications in these patients. ${ }^{6}$ In children, routine use of $\mathrm{z}$ scores for surgical decision-making has not been validated. Routine echocardiographic imaging should be supplemented with additional cross-sectional imaging with computed tomography/magnetic resonance imaging (MRI). Both computed tomography and MRI have excellent reproducibility in double oblique measurements. ${ }^{6}$ Newer markers such as vertebral artery tortuosity obtained from MRI with a value above 50 has been shown to associated with earlier age of dissection and death. ${ }^{7}$ Additional markers for vascular phenotype in these patients that assess the vessel stiffness (strain, distensibility, and beta stiffness index) can be obtained from MRI. Greater strain values obtained from MRI have been shown to be associated with increased rate of dissection and death, ${ }^{8}$ suggesting a combination of all these modalities should be used in guiding surgical decisions. 
Although guidelines exist on the management of thoracic aortic diseases, the most recent guidelines do not provide a clear management decision on how to manage aortic dilatation in conotruncal defects. ${ }^{9}$ While aortic dilatation is common in conotruncal defects, the rarity of complications in these patients would make it difficult to suggest absolute threshold measurements to guide surgical decision making. ${ }^{10}$ Fewer than 10 case reports of aortic dissection in tetralogy of Fallot have been published, with most patients who dissected having had an absolute ascending aortic diameter above $6 \mathrm{~cm} .{ }^{11}$ No case of dissection in transposition patients has been published. ${ }^{11}$ What is uncertain is why conotruncal defects are at risk for dilation. Is it related to intrinsic histologic abnormalities suggesting an intrinsic aortopathy similar to connective tissue disorders in the aortic root or is it the presence of hemodynamic factors that promote increase flow through the aorta, such as pulmonary atresia, systemic to pulmonary shunt, older age at repair, or genetic factors such as DiGeorge syndrome? Given the earlier age of operation in these patients, it is unclear whether significant aortic dilatation would be seen in the future in those who are operated on in the first year of life. When deciding on prophylactic surgery in patients with conotruncal defects presenting with aneurysmal dilatation of the aorta, additional factors, such as number of previous open-heart surgeries, the rate of growth of aorta, the presence of concurrent cardiac lesions such as aortic valve insufficiency and, most importantly, either a personal or family history that would suggest aortopathy such as a positive genetic mutation or family history of aortic aneurysm/ dissection. ${ }^{11}$

Overall, the authors present a complete present-day review of the VSRR operations used in congenital cardiac patients. With the reimplantation technique followed by the remodeling technique being the most commonly used procedures, it remains to be seen what role the external wrapping/supporting procedures will play in congenital aortic disease. Indications for prophylactic VSRR continue to evolve as we learn more about this growing population.

\section{References}

1. David TE, David CM, Feindel CM, Manlhiot C. Reimplantation of the aortic valve at 20 years. J Thorac Cardiovasc Surg. 2017;153:232-8.

2. De Paulis R, Chirichilli I, Scaffa R, Weltert L, Maselli D, Salica A, et al. Longterm results of the valve reimplantation technique using a graft with sinuses. $J$ Thorac Cardiovasc Surg. 2016;151:112-9.

3. Fraser CD, Liu RH, Zhou X, Patel ND, Lui C, Pierre AS, et al. Valve-sparing aortic root replacement in children: outcomes from 100 consecutive cases. $J$ Thorac Cardiovasc Surg. 2019;157:1100-9.

4. Myers PO, del Nido PJ, Emani S, Marx GR, Baird CW. Valve-sparing aortic root replacement and remodeling with complex aortic valve reconstruction in children and young adults with moderate or severe aortic regurgitation. J Thorac Cardiovasc Surg. 2014;147:1768-76.

5. Buratto E, Konstantinov IE. Valve-sparing aortic root surgery in children and adults with congenital heart disease. J Thorac Cardiovasc Surg. 2021;162: 955-62.

6. Nejatian A, Yu J, Geva T, White MT, Prakash A. Aortic measurements in patients with aortopathy are larger and more reproducible by cardiac magnetic resonance compared with echocardiography. Pediatr Cardiol. 2015;36:1761-73.

7. Morris SA, Orbach DB, Geva T, Singh MN, Gauvreau K, Lacro RV. Increased vertebral artery tortuosity index is associated with adverse outcomes in children and young adults with connective tissue disorders. Circulation. 2011;124: 388-96.

8. Prakash A, Adlakha H, Rabideau N, Hass CJ, Morris SA, Geva T, et al. Segmental aortic stiffness in children and young adults with connective tissue disorders: relationships with age, aortic size, rate of dilation, and surgical root replacement. Circulation. 2015;132:595-602.

9. ACCF/AHA/AATS/ACR/ASA/SCA/SCAI/SIR/STS/SVM guidelines for the diagnosis and management of patients with thoracic aortic disease. J Am Coll Cardiol. 2010;55:e27-129.

10. Stulak JM, Dearani JA, Burkhart HM, Sundt TM, Connolly HM, Schaff HV. Does the dilated ascending aortae in an adult with congenital heart disease require intervention? J Thorac Cardiovasc Surg. 2010;140(6 suppl):S52-91.

11. Kay WA. Molecular and genetic insights into thoracic aortic dilation in conotruncal heart defects. Front Cardiovasc Med. 2016;3:18. 